\title{
Peningkatan mutu blanket karet alam melalui proses predrying dan penyemprotan asap cair
}

\section{The quality improvement of natural rubber blanket through predrying process and liquid smoke spraying}

\author{
Afrizal Vachlepi \\ Balai Penelitian Sembawa - Pusat Penelitian Karet, Jl. Raya Palembang - Betung km. 29 Palembang 30001, Indonesia \\ Telp: +627117439493, Fax.: +627117439282 \\ E-mail: a_vachlepi@yahoo.com
}

Diterima: 17 Oktober 2016 Direvisi: 21 Maret 2017 Disetujui: 3 April 2017

\begin{abstract}
Most of Indonesian rubber products SIR 20 are made from the material of raw rubber obtained from smallholders. However, the quality of this material is not good enough. Thus, quality improvement has to be carried out by manufacturers. The liquid smoke used during the blanket hanging process can improve the quality of the rubber products SIR 20. This research aimed to determine and study the effects of liquid smoke spraying and blanket hanging duration on the drying factor, the dry rubber content, technical quality, vulcanization characteristics, and physical properties of vulcanized natural rubber. Treatments consisted of various hanging duration (6, 8, and 10 days, and without hanging) and spraying (with and without spraying of liquid smoke). The results showed that the spraying of liquid smoke on natural rubber blankets could improve the technical quality of the natural rubber, especially the values of Po and PRI. The spraying of liquid smoke could reduce the blanket hanging duration to 6-8 days. The blankets sprayed with liquid smoke had the optimum cure time of around 15 minutes and 19 seconds and the scorch time of around 3 minutes and 22 seconds. These values indicated that the vulcanization characteristics of blankets which were sprayed with liquid smoke were generally better than those of blankets which were not sprayed with liquid smoke.
\end{abstract}

Keywords: liquid smoke, natural rubber, blanket quality, hanging.

\begin{abstract}
ABSTRAK
Produk karet SIR 20 Indonesia sebagian besar diproduksi dengan menggunakan bahan olah karet petani. Mutu bahan olah karet ini masih belum baik. Peningkatan mutu harus dilakukan di tingkat pabrik. Penggunaan asap cair pada proses penggantung blanket dapat meningkatkan mutu produk karet SIR 20. Tujuan penelitian ini adalah untuk mengetahui dan mempelajari pengaruh penyemprotan asap cair dan waktu penggantungan blanket terhadap faktor pengeringan, kadar karet kering, mutu teknis, karakteristik vulkanisasi dan sifat fisik vulkanisat karet alam. Perlakuan yang diberikan terdiri atas waktu penggantungan $(6,8,10$ hari, dan tanpa penggantungan) dan penyemprotan (dengan penyemprotan asap cair dan tanpa penyemprotan). Hasil penelitian menunjukkan bahwa aplikasi penyemprotan asap cair pada blanket karet alam dapat meningkatkan mutu teknis karet alam terutama nilai Po dan PRI. Dengan penyemprotan asap cair, lama penggantungan blanket dapat dipercepat menjadi 6-8 hari. Blanket yang disemprot asap cair mempunyai waktu matang optimum sekitar 15 menit 19 detik dan waktu terjadinya pravulkanisasi sekitar 3 menit 22 detik. Nilai ini secara umum menunjukkan karakteristik vulkanisasi blanket disemprot asap cair lebih baik dibandingkan blanket tanpa penyemprotan.
\end{abstract}

Kata kunci: asap cair, karet alam, mutu blanket, penggantungan.

\section{PENDAHULUAN}

Indonesia merupakan negara penghasil karet alam terbesar kedua di dunia setelah Thailand. Total ekspor karet alam Indonesia tahun 2014 seki- tar 2,62 juta ton dengan nilai mencapai 4,74 miliar USD (Ditjenbun, 2015). Produk ekspor karet alam Indonesia sebagian besar berupa karet remah jenis mutu SIR 20 yang mencapai $92 \%$ dari to- 
tal produksi karet Indonesia. Karet remah adalah produk karet alam yang merupakan produk setengah jadi dan pengolahannya melalui tahap peremahan (Supraptiningsih \& Sarengat, 2014).

Bahan baku untuk memproduksi karet SIR 20 umumnya berasal dari bahan olah karet (bokar) petani. Oleh karena itu mutu bokar petani sangat mempengaruhi mutu karet SIR 20 yang diproduksi. Hasil survei yang dilakukan Syarifa et al. (2013) di Sumatera Selatan sebagai provinsi penghasil karet alam terbesar di Indonesia mendapatkan bahwa mutu bokar petani masih belum baik. Sebagian petani masih mencampurkan kontaminan seperti tatal (kulit kayu sadapan) ke dalam bokar. Selain itu, masih banyak ditemukan petani yang menggunakan bahan penggumpal (koagulan) yang tidak direkomendasi (Syarifa et al., 2013).

Penggunaan bahan penggumpal yang tidak direkomendasi menyebabkan tingginya kadar abu dan rendahnya plastisitas awal karet (Wiyanto \& Kusnadi, 2013). Kebiasaaan-kebiasaan petani yang menyebabkan kualitas karet rakyat belum baik terjadi karena masih rendahnya kesadaran petani karet dalam melakukan pemeliharaan pada tanaman karet dari awal sampai tahap pemanenan dan pengolahan (Sannia et al., 2013). Agar memenuhi standar ekspor, peningkatan mutu perlu dilakukan terutama di tingkat pabrik pengolahan karet remah.

Metode yang paling umum digunakan pabrik karet remah untuk meningkatkan mutu adalah penggantungan (predrying). Metode ini dapat meningkatkan nilai plastisitas karet alam. Penelitian Aguele et al. (2015) membuktikan bahwa karet alam yang dikeringkan dengan menggunakan udara (kering-angin) mempunyai nilai plastisitas paling tinggi. Lama penggantungan blanket yang umumnya dilakukan pabrik karet remah sekitar 10-12 hari. Penggantungan blanket ini akan menimbulkan bau busuk di sekitar pabrik karet remah terutama saat angin bertiup. Bahkan tidak jarang bau busuk tersebut dapat tercium cukup jauh dari pabrik karet remah.

Metode lain yang dapat dilakukan untuk meningkatkan mutu karet alam adalah menggunakan asap cair. Penggunaan asap cair dalam pengolahan karet alam terbukti mampu menghasilkan karet alam bermutu baik sesuai dengan persyaratan Standar Nasional Indonesia (SNI) 06-1903-2000 tentang Standard Indonesian Rubber (SIR). Asap cair umumnya digunakan sebagai bahan penggumpal (koagulan) lateks dan penghilang bau busuk.

Hasil penelitian Tedjaputra et al. (2007) menyatakan bahwa asap cair dapat diaplikasikan dalam pengolahan karet sebagai bahan koagulasi (penggumpalan) dan pengendalian bau busuk ( $m a-$ lodor). Kemampuan asap cair menggumpalkan lateks disebabkan kandungan asam asetat yang terdapat pada asap cair. Sedangkan pengendalian bau busuk oleh asap cair lebih disebabkan kandungan fenol dan senyawa aromatik lainnya. Fenol mampu berfungsi sebagai antimikrobia yang dapat mencegah terjadinya pertumbuhan mikroorganisme pada blanket karet (Karseno \& Rahayu, 2002). Mikroorganisme tersebut akan merusak protein pada partikel karet alam dan menghasilkan $\mathrm{H}_{2} \mathrm{~S}$ yang menyebabkan bau busuk (Solichin, 2007). Penelitian Prasetyowati et al. (2014) menyatakan bahwa asap cair mengandung asam asetat dan fenol yang cukup tinggi.

Beberapa teknik atau cara penggunaan asap cair pada proses pengolahan karet alam antara lain penggumpalan, perendaman, dan penyemprotan. Penelitian aplikasi penyemprotan asap cair pada blanket karet alam masih belum banyak dilakukan.

Tujuan penelitian ini adalah untuk mengetahui dan mempelajari pengaruh penyemprotan asap cair dan waktu penggantungan blanket terhadap faktor pengeringan, kadar karet kering, mutu teknis, karakteristik vulkanisasi, dan sifat fisik vulkanisat karet alam. Asap cair yang disemprotkan ke blanket karet alam akan berfungsi sebagai antimikrobia dan mencegah bau busuk. Dengan menekan pertumbuhan mikroorganisme, proses degradasi protein pada partikel karet alam yang dilakukan mikroorganisme akan berkurang sehingga tidak merusak partikel karet alam dan tidak menimbulkan bau busuk.

\section{BAHAN DAN METODE Bahan Penelitian}

Bahan yang digunakan terdiri dari koagulum karet alam berupa $s l a b$ yang berasal dari petani, asap cair merek Deorub produksi PT. Global Deorub Industry, dan bahan kimia untuk pembuatan kompon standar berupa $\mathrm{ZnO}$, asam stearat, sulfur dan mercaptobenzothiazole dari penyuplai lokal dengan mutu rubber grade (Tabel 2). Dari hasil analisis menggunakan automated thermal desorption coupled gas chromatography-mass selective detector (ATD-GC-MSD), asap cair Deorub mengandung $21,9 \%$ senyawa mudah menguap (vola- 
til), $77,5 \%$ air, dan sisanya $0,6 \%$ senyawa tidak menguap. Senyawa-senyawa mudah menguap di dalam asap cair Deorub antara lain berupa dimetil ester asam karbonat, propana, fenol, metoksi fenol, siklopentana, benzena, dan furan.

\section{Peralatan Penelitian}

Peralatan yang digunakan antara lain mesin creeper untuk pembuatan blanket, timbangan, oven, Rapid Wallace plastimeter, mesin gilingan terbuka (open mill), desikator, stopwatch dan reometer.

\section{Metode Penelitian}

Penelitian ini dilakukan dalam skala pabrik pengolahan karet remah. Perlakuan yang diberikan terdiri atas waktu penggantungan (predrying) dan penyemprotan. Waktu penggantungan divariasikan berturut-turut $6,8,10$ hari, dan tanpa penggantungan (kontrol). Penyemprotan divariasikan berupa penyemprotan dengan asap cair dan tanpa penyemprotan (kontrol).

\section{Parameter pengamatan}

Parameter yang diamati pada penelitian ini terdiri atas faktor pengeringan, kadar karet kering (KKK), mutu teknis, karakteristik vulkanisasi dan sifat fisik vulkanisat. Untuk parameter karakteristik vulkanisasi dan sifat fisik vulkanisat dilakukan di Laboratorium Fisika di Pusat Penelitian Karet, Bogor.

\section{Pembuatan blanket karet}

Kegiatan penelitian ini diawali dengan penyiapan bahan olah karet (bokar) berupa slab dengan total sekitar $1.000 \mathrm{~kg}$. Slab tersebut dibagi menjadi dua bagian masing-masing $500 \mathrm{~kg}$ untuk setiap perlakuan penyemprotan asap dan tanpa penyemprotan. Setiap bokar perlakuan digiling menggunakan mesin giling (mesin creeper) menjadi blanket. Untuk blanket yang diberikan perlakuan penyemprotan, tahap selanjutnya proses penyemprotan blanket menggunakan larutan asap cair $10 \%$ dengan dosis $1 \% \mathrm{~b} / \mathrm{b}$ basah blanket karet.

Tahap berikutnya blanket setiap perlakuan (blanket disemprot asap cair dan tanpa penyemprotan) dikeringanginkan (predrying) dengan cara penggantungan sesuai dengan perlakuan waktu penggantungan (Gambar 1). Pengambilan sampel dilakukan setiap hari sesuai dengan perlakuan waktu penggantungan untuk dilakukan analisis berdasarkan parameter pengamatan.

\section{Analisis faktor pengeringan dan kadar karet kering}

Analisis faktor pengeringan dan kadar karet kering (KKK) dilakukan dengan menimbang bahan atau produk yang dihasilkan pada setiap tahapan proses. Parameter faktor pengeringan dihitung menggunakan persamaan sebagai berikut:

$F_{p}(\%)=\frac{X_{1}}{B_{1}} \times 100 \%$

Parameter mutu KKK dihitung menggunakan persamaan sebagai berikut :

$\operatorname{KKK}(\%)=\frac{\mathrm{X}_{1}}{\mathrm{~B}_{0}} \times 100 \%$

$\mathrm{F}_{\mathrm{p}}$ adalah faktor pengeringan, KKK adalah kadar karet kering, $\mathrm{B}_{0}$ adalah bobot blanket basah (sebelum penggantungan), $\mathrm{B}_{1}$ adalah bobot blanket kering (sesudah penggantungan), dan $\mathrm{X}_{1}$ adalah bobot kering karet.

\section{Analisis mutu teknis}

Karet yang sudah kering selanjutnya akan dianalisis mutu teknisnya berupa plastisitas terdiri atas plastisitas awal (Po) dan indeks ketahanan plastisitas (plasticity retention index/PRI). Mutu teknis karet yang dihasilkan akan dibandingkan dengan standar mutu yang tercantum dalam Standar Nasional Indonesia (SNI) 06-1903-2000 tentang Standard Indonesian Rubber (SIR) untuk jenis mutu SIR 20 pada Tabel 1 (BSN, 2000).

\section{Pembuatan kompon}

Karet yang sudah dikeringkan selanjutnya akan diproses menjadi kompon standar ASTM 1A menggunakan gilingan terbuka (open mill) berkapasitas sekitar $1 \mathrm{~kg}$. Sebelum digunakan, gilingan

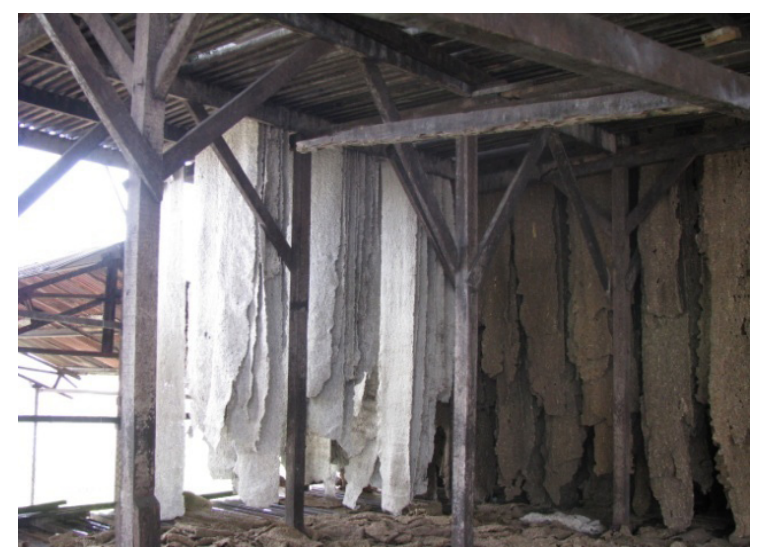

Gambar 1. Penggantungan blanket berbagai perlakuan. 
tersebut dipanaskan hingga mencapai suhu $70^{\circ} \mathrm{C}$ $\pm 5^{\circ} \mathrm{C}$. Setelah gilingan panas, karet dan bahan kimia yang telah ditimbang sesuai dengan formula seperti pada Tabel 2 digiling dan dipotong secara bergantian bagian kiri/kanan hingga bahan-bahan tercampur dengan baik dan karet menjadi plastis. Hasil penggilingan yang berbentuk lembaran kompon, didiamkan selama 24 jam pada suhu kamar.

\section{Analisis karakteristik vulkanisasi dan sifat fisik vulkanisat}

Lembaran kompon standar dianalisis karakteristik vulkanisasinya menggunakan reometer dengan suhu $140^{\circ} \mathrm{C}$. Hasil analisis karakteristik vulkanisasi berupa modulus torsi, waktu matang optimum dan waktu pravulkanisasi. Tahap berikutnya lembaran kompon divulkanisasi dalam bentuk lembaran dengan ukuran $15 \times 15 \times 2 \mathrm{~mm}$ pada suhu $140^{\circ} \mathrm{C}$ dengan waktu sesuai dengan waktu matang optimum dari hasil analisis karakteristik vulkanisasi.

Hasil vulkanisasi yang berupa vulkanisat karet selanjutnya dibiarkan selama 24 jam pada suhu kamar. Produk vulkanisat karet tersebut dianalisis sesuai dengan parameter pengamatan sifat fisik vulkanisat berupa kekerasan dengan menggunakan alat Shore A Durometer metode uji ASTM D2240-97, tegangan putus, tegangan tarik 500\% dan perpanjangan putus. Pengujian ketiga para-

Tabel 1. Persyaratan mutu SNI 06-1903-2000 tentang SIR.

\begin{tabular}{lc}
\hline \multicolumn{1}{c}{ Spesifikasi/(asal bahan olah) } & SIR 20 \\
\cline { 2 - 3 } & Koagulum \\
\hline Kadar kotoran,\% maks (b/b) & 0,20 \\
Kadar abu, \% maks (b/b) & 1,00 \\
Kadar zat menguap, \% maks (b/b) & 0,80 \\
PRI, min & 50 \\
Po, min & 30 \\
Nitrogen (N), maks (b/b) & 0,60 \\
Viskositas Mooney Ml (1+4)100 & - \\
\hline
\end{tabular}

Tabel 2. Formula kompon standar 1A.

\begin{tabular}{lc}
\hline \multicolumn{1}{c}{ Bahan } & Formula $(p h r)$ \\
\hline Karet & 100,00 \\
ZnO & 6,00 \\
Sulfur & 3,50 \\
Asam stearat & 0,50 \\
Mercaptobenzothiazole & 0,50 \\
\hline Total & 110,50 \\
\hline
\end{tabular}

meter terakhir menggunakan metode uji ASTM D412-97 dan menggunakan alat tensometer, kecepatan $500 \mathrm{~mm} / \mathrm{menit}$. Formula kompon standar 1A menurut ASTM yang digunakan disajikan pada Tabel 2 (ASTM, 2014).

\section{HASIL DAN PEMBAHASAN}

Faktor Pengeringan dan Kadar Karet Kering

Hasil pengamatan faktor pengeringan dan kadar karet kering (KKK) dari blanket pada berbagai perlakuan disajikan pada Gambar 2 dan Gambar 3. Faktor pengeringan blanket diperoleh dari hasil perhitungan menggunakan persamaan (1). Sedangkan KKK diperoleh dari perhitungan menggunakan persamaan (2).

Seperti terlihat pada Gambar 2 faktor pengeringan blanket tidak dipengaruhi perlakuan penyemprotan, tetapi lebih dipengaruhi perlakuan penggantungan. Faktor pengeringan merupakan persentase perubahan bobot blanket sebelum dan sesudah proses pengeringan. Blanket tanpa penggantungan (kontrol) mempunyai faktor pengeringan paling rendah dibandingkan blanket yang digantung (predrying).

Faktor pengeringan blanket yang digantung sekitar 80,94-83,83\%. Sedangkan blanket tanpa penggantungan (kontrol) hanya berkisar antara $67,11-73,17 \%$. Tingginya faktor pengeringan blanket yang digantung terjadi karena adanya proses penguapan air yang terkandung dalam blanket. Akibatnya bobot blanket menjadi lebih ringan dan sudah mendekati bobot keringnya. Selisih bobot blanket kering dengan bobot basahnya yang kecil menunjukkan faktor pengeringan yang besar.

Hasil yang sama juga diperoleh dari pengamatan KKK blanket. Berdasarkan Gambar 3 diketahui bahwa KKK blanket tidak dipengaruhi oleh perlakuan penyemprotan, tetapi hanya dipengaruhi perlakuan penggantungan. Perlakuan penyem-

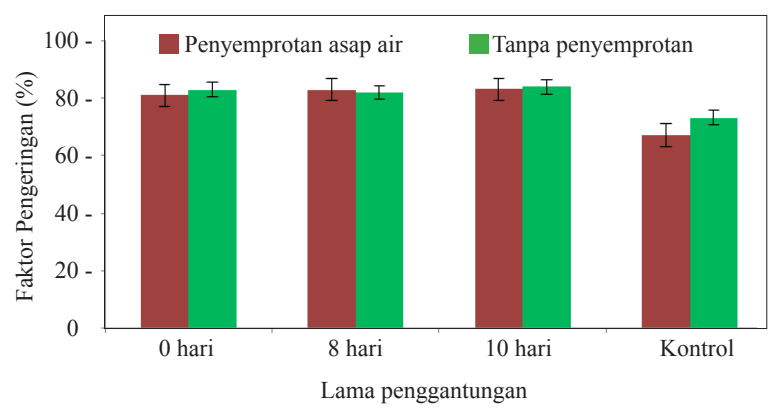

Gambar 2. Faktor pengeringan blanket berbagai perlakuan. 


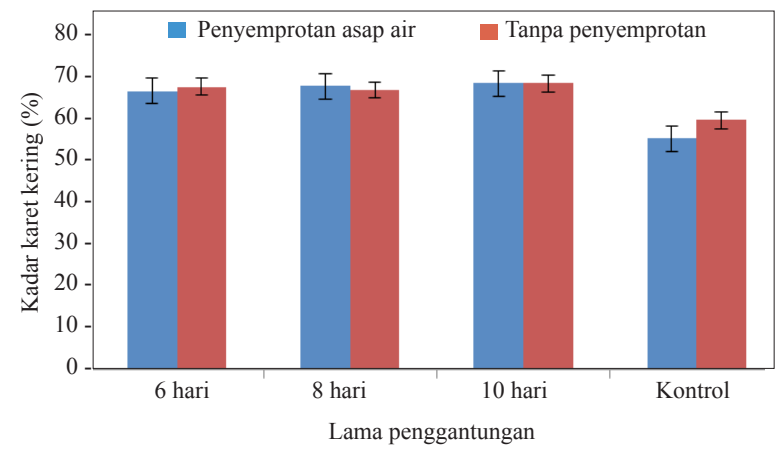

Gambar 3. Kadar karet kering (KKK) blanket berbagai perlakuan.

protan tidak mempengaruhi KKK blanket karena jumlah asap cair yang disemprotkan sedikit hanya $1 \% \mathrm{~b} / \mathrm{b}$ blanket basah. Jumlah tersebut tidak memberikan perubahan yang signifikan terhadap bobot basah blanket. Oleh karena itu perlakuan penyemprotan tidak berpengaruh terhadap KKK blanket.

Perlakuan penggantungan berpengaruh terhadap KKK. Hal ini terjadi karena selama penggantungan, air yang terkandung dalam blanket mengalami penguapan. Akibat proses penguapan tersebut, bobot basah blanket mengalami perubahan menjadi lebih rendah atau blanket menjadi lebih kering. Sedangkan bobot padatan karet (bobot kering) tidak mengalami perubahan. Oleh karena itulah KKK blanket akan berubah selama proses penggantungan.

Berdasarkan Gambar 3 diketahui bahwa KKK blanket tanpa penggantungan (kontrol) lebih rendah dibandingkan blanket yang digantung. Blanket tanpa penggantungan mempunyai KKK berkisar antara 54,01-58,38\%. Sementara itu, blanket yang diberi perlakuan penggantungan mempunyai KKK sekitar 65,15-66,89\%.

Tingginya KKK yang digantung disebabkan rendahnya kandungan air pada blanket akibat terjadinya proses penguapan selama penggantungan. Dalam koagulum karet alam (blanket), selain partikel karet juga mengandung bahan lain (Jayanthy \& Sankaranarayanan, 2005) seperti air. KKK adalah persentase kandungan partikel karet alam (poliisoprena) yang terdapat pada bahan olah karet dalam hal ini blanket. KKK merupakan istilah yang sudah umum digunakan dalam industri pengolahan karet alam (Kumar et al., 2007).

Keuntungan KKK yang tinggi pada blanket adalah proses pengeringan dapat dilakukan lebih cepat karena jumlah air yang harus diuapkan sudah lebih sedikit. Pengeringan merupakan proses penting untuk mengurangi kandungan air bahan dan memastikan mutu produk yang konsisten $(\mathrm{Ng}$ et al., 2015). Proses pengeringan yang cepat ini akan meningkatkan efisiensi biaya produksi. Tham et al. (2014) dan Ekphon et al. (2013) menyatakan bahwa proses pengeringan merupakan salah satu proses yang memerlukan energi cukup besar dalam industri karet alam. Dengan semakin rendahnya kadar air, maka waktu pengeringan menjadi lebih singkat sehingga energi yang diperlukan pun menjadi lebih rendah atau lebih efisien.

\section{Plastisitas Karet Alam}

Hasil analisis parameter mutu plastisitas awal (Po) dan indeks ketahanan plastisitas (PRI) karet alam disajikan pada Gambar 4 dan Gambar 5. Nilai Po dan PRI merupakan parameter dasar untuk menentukan mutu karet lembaran (Achmadi et al., 2015), seperti blanket.

Seperti terlihat pada Gambar 4 diketahui bahwa perlakuan penyemprotan dan waktu penggantungan berpengaruh terhadap nilai Po blanket karet alam. Blanket yang diberi perlakuan penyemprotan dengan asap cair mempunyai nilai Po yang lebih tinggi dibandingkan perlakuan lainnya. Meskipun awalnya nilai Po blanket yang disemprot asap cair hanya 30,7 (tanpa penggantungan),

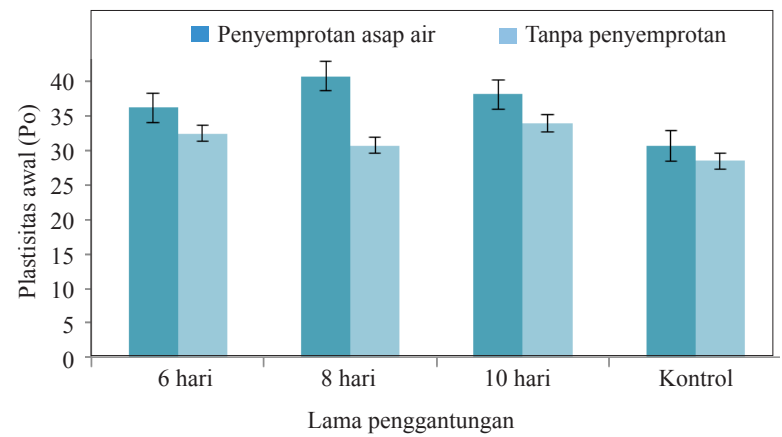

Gambar 4. Nilai plastisitas awal karet pada berbagai perlakuan.

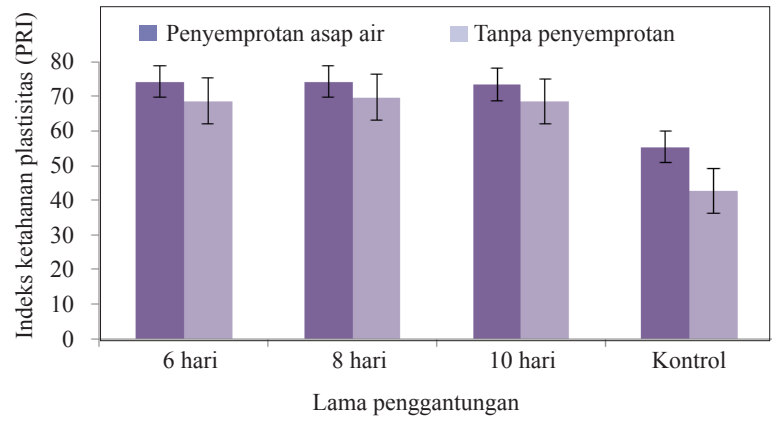

Gambar 5. Nilai indeks ketahanan plastisitas karet pada berbagai perlakuan. 
tetapi setelah dilakukan penggantungan terjadi peningkatan menjadi 36,3-40,8. Nilai Po blanket yang disemprot asap cair secara umum memenuhi persyaratan mutu SIR 20 seperti yang tercantum dalam SNI 06-1903-2000 yang syarat minimalnya adalah 30 (Tabel 1).

Peningkatan nilai Po selama proses penggantungan juga terjadi pada blanket tanpa penyemprotan. Nilai Po blanket tanpa penyemprotan yang awalnya hanya 28,5 (tanpa penggantungan) meningkat menjadi sekitar 30,8-34,0 setelah proses penggantungan (predrying).

Pengujian indeks ketahanan plastisitas (PRI) dilakukan untuk mengukur ketahanan karet mentah terhadap degradasi oleh oksidasi pada suhu tinggi. Nilai PRI yang tinggi menunjukkan bahwa karet alam tahan terhadap suhu tinggi. Persyaratan mutu untuk parameter PRI berdasarkan SNI 061903-2000 yaitu minimal 50 (Tabel 1).

Hasil penelitian menunjukkan bahwa perlakuan penyemprotan dan penggantungan (predrying) berpengaruh terhadap nilai PRI (Gambar 5). Blanket tanpa penyemprotan (kontrol) mempunyai nilai PRI yang lebih rendah dibandingkan dengan blanket asap cair. Nilai PRI yang rendah pada blanket tanpa penyemprotan disebabkan bokar yang digunakan berasal dari petani. Solichin dan Anwar (2003) menyatakan bahwa masalah utama yang dihadapi oleh petani adalah rendahnya mutu bokar karena bahan pembeku yang digunakan tidak dapat mencegah pertumbuhan bakteri yang merusak protein sehingga nilai Po dan PRI-nya rendah (Solichin \& Anwar, 2003). Penggumpalan spontan yang dilakukan petani akibat penggunaan koagulan bukan rekomendasi juga menjadi penyebab rendahnya nilai plastisitas karet alam (Zhong et al., 2009).

Nilai PRI yang lebih besar pada blanket yang disemprot asap cair menunjukkan bahwa blanket karet tersebut tahan terhadap oksidasi oleh suhu tinggi. Besarnya nilai Po dan PRI blanket yang disemprot asap cair disebabkan senyawa kimia yang terkandung dalam asap cair. Asap cair mengandung sekitar 67 jenis senyawa yang dapat berfungsi sebagai antibakteri, antioksidan, pemberi warna coklat, dan bau asap yang khas (Karseno \& Rahayu, 2002; Solichin et al., 2005). Senyawa fenol atau turunannya yang terdapat pada asap cair dapat berfungsi sebagai antioksidan yang akan melindungi molekul karet pada suhu tinggi sehingga nilai PRI-nya tetap tinggi (Solichin, 2005; Prasertsit et al., 2011).
Nilai PRI blanket semua perlakuan yang berkisar antara 55,4-74,3 secara umum memenuhi persyaratan SNI, kecuali blanket tanpa penyemprotan dan tanpa penggantungan. Blanket karet yang tidak digantung dan tidak semprot asap cair hanya mempunyai nilai PRI sebesar 42,7. Angka ini tidak memenuhi standar mutu SNI yang mensyaratkan nilai PRI minimal 50 (Tabel 1). Tetapi nilai tersebut mengalami perubahan selama proses penggantungan.

Perubahan nilai plastisitas (Po dan PRI) blanket karet alam yang terjadi selama penggantungan disebabkan perubahan kondisi lingkungan. Hal ini sesuai dengan penelitian Intapun et al. (2009) yang menyatakan bahwa kondisi lingkungan (suhu, $\mathrm{pH}$, dan oksigen dalam udara) selama penyimpanan mempengaruhi sensibilitas karet alam terhadap oksidasi suhu tinggi. Faktor tersebut juga terjadi karena adanya perubahan keseimbangan antara senyawa antioksidan (protein, asam amino, tocotrieniols) dan prooksidan asam lemak bebas tak jenuh dan ion logam bebas) dalam karet alam.

Berdasarkan hasil analisis parameter mutu Po dan PRI, blanket yang disemprot dengan asap cair tidak perlu dilakukan penggantungan selama 1012 hari seperti yang umum dilakukan pabrik karet remah. Dengan penyemprotan asap cair, lama penggantungan blanket dapat dipersingkat menjadi 6-8 hari karena nilai Po dan PRI sudah memenuhi persyaratan SNI. Hasil penelitian Vachlepi dan Solichin (2008) juga membuktikan bahwa karet alam yang digumpalkan dengan formula asap cair mempunyai plastisitas (Po dan PRI) yang lebih tinggi, yaitu 43 dan 89 .

\section{Karakteristik Vulkanisasi}

Proses vulkanisasi kompon karet merupakan suatu reaksi kimiawi yang bersifat tidak dapat balik (irreversible) melalui pembentukan ikatan silang oleh bahan pemvulkanisasi pada rantai molekul karet. Hasil pengujian karakteristik vulkanisasi memberikan informasi tentang derajat/tingkat vulkanisasi kompon karet. Derajat vulkanisasi dapat diperkirakan melalui selisih antara modulus torsi maksimum (S'maks) dengan modulus torsi minimum (S'min). Derajat vulkanisasi ini menunjukkan derajat ikatan silang yang terbentuk (Cifriadi, 2013). Delta $\mathrm{S}(\Delta \mathrm{S})$ dapat diindikasikan secara tidak langsung sebagai pembentukan jaringan dalam sistem ikatan silang (Jovanovici et al., 2009).

Data analisis karakteristik vulkanisasi kompon dari blanket berbagai perlakuan ditampilkan pada 
Tabel 3. Hasil analisis menunjukkan bahwa secara umum modulus torsi kompon dari blanket yang disemprot dengan asap cair lebih tinggi dibandingkan tanpa penyemprotan. Modulus yang besar menunjukkan tingkat kerapatan ikatan yang terbentuk juga besar.

Waktu matang optimum dan waktu pravulkanisasi kompon dari blanket yang disemprot asap cair secara umum lebih cepat dibandingkan tanpa penyemprotan. Waktu proses vulkanisasi yang lebih cepat pada blanket yang disemprot asap cair lebih disebabkan oleh kandungan senyawa kimia yang terdapat pada asap cair, seperti senyawa golongan asam lemak. Suparto dan Santosa (2008) menyatakan bahwa senyawa organik seperti asam lemak dapat digunakan untuk proses vulkanisasi. Proses vulkanisasi biasanya memerlukan bahanbahan aditif yang berfungsi sebagai pemvulkanisasi, pencepat, dan penggiat.

Waktu vulkanisasi, baik pravulkanisasi maupun matang optimum, yang lebih cepat ini sangat diperlukan untuk proses produksi yang banyak (massal) hubungannya dengan efisiensi waktu dan penggunaan energi. Kompon dengan waktu masak yang cepat akan lebih efisien apabila akan diproduksi secara massal.

Kompon dari blanket yang disemprot asap cair dan dilakukan proses penggantungan (predrying) mempunyai waktu matang optimum sekitar 14 menit 54 detik sampai 15 menit 19 detik dan waktu pravulkanisasi berkisar antara 3 menit 17 detik sampai 3 menit 26 detik. Angka ini masih lebih cepat dibandingkan tanpa penyemprotan yaitu sekitar 15 menit 15 detik sampai 16 menit 2 detik untuk waktu matang optimum dan 3 menit 31 detik sampai 3 menit 42 detik.

\section{Sifat Fisik Vulkanisat}

Hasil analisis sifat fisik dari vulkanisat yang diproduksi dari blanket berbagai perlakuan disajikan pada Tabel 4. Dari analisis tersebut diketahui bahwa perlakuan penyemprotan dan penggantungan (predrying) tidak berpengaruh terhadap kekerasan, kuat tarik, dan modulus 500\% dari vulkanisat yang dihasilkan.

Meskipun tidak berpengaruh secara signifikan, kekerasan vulkanisat yang diproduksi dari blanket disemprot asap cair sedikit lebih tinggi dibandingkan tanpa penyemprotan. Kondisi ini diduga disebabkan tingkat kerapatan (derajat) vulkanisasi kompon karet yang dibuat dari blanket dengan penyemprotan asap lebih besar. Hal ini sesuai hasil analisis parameter modulus dari kompon karet (Tabel 3). Kerapatan vulkanisasi akan mempengaruhi sifat fisik vulkanisat (Suparto \& Santosa, 2008).

Kekerasan blanket yang disemprot asap cair sebesar 38 Shore A. Sementara itu, blanket tanpa penyemprotan sekitar 36-38 Shore A. Angka ini memberikan informasi bahwa vulkanisat dari blanket yang disemprot asap cair cenderung lebih keras dibandingkan tanpa penyemprotan.

Tabel 3. Karakteristik vulkanisasi karet pada berbagai perlakuan.

\begin{tabular}{|c|c|c|c|c|c|c|c|c|}
\hline \multirow{2}{*}{$\begin{array}{l}\text { Parameter } \\
\text { pengamatan }\end{array}$} & \multicolumn{4}{|c|}{ Penyemprotan asap cair } & \multicolumn{4}{|c|}{ Tanpa penyemprotan } \\
\hline & 6 hari & 8 hari & 10 hari & Kontrol & 6 hari & 8 hari & 10 hari & Kontrol \\
\hline S'maks (kg-cm) & $7,01 \mathrm{a}$ & $7,00 \mathrm{a}$ & $6,81 \mathrm{a}$ & $7,14 \mathrm{a}$ & $6,55 \mathrm{a}$ & $6,76 \mathrm{a}$ & $6,71 \mathrm{a}$ & $6,94 \mathrm{a}$ \\
\hline $\begin{array}{l}\mathrm{S}^{\prime} \min \\
(\mathrm{kg}-\mathrm{cm})\end{array}$ & $0,61 \mathrm{ab}$ & $0,71 \mathrm{a}$ & $0,74 \mathrm{a}$ & $0,37 b$ & $0,40 \mathrm{~b}$ & $0,57 \mathrm{ab}$ & $0,48 \mathrm{ab}$ & $0,73 \mathrm{a}$ \\
\hline $\begin{array}{l}\mathrm{S}^{\prime} \mathrm{maks}^{\prime} \mathrm{S}^{\prime} \min (\Delta \mathrm{S}) \\
(\mathrm{kg}-\mathrm{cm})\end{array}$ & $6,40 \mathrm{a}$ & $6,29 \mathrm{a}$ & $6,07 a$ & $6,77 \mathrm{a}$ & $6,15 \mathrm{a}$ & $6,19 \mathrm{a}$ & $6,23 \mathrm{a}$ & $6,21 \mathrm{a}$ \\
\hline $\begin{array}{l}\text { Waktu matang } \\
\text { optimum (min.dtk) }\end{array}$ & $15.19 \mathrm{a}$ & $14.54 \mathrm{a}$ & $15.11 \mathrm{a}$ & $15.34 \mathrm{a}$ & $15.15 \mathrm{a}$ & $15.38 \mathrm{a}$ & $16.02 \mathrm{a}$ & $15.11 \mathrm{a}$ \\
\hline $\begin{array}{l}\text { Waktu pra- } \\
\text { vulkanisasi (min. } \\
\text { dtk) }\end{array}$ & $3.22 \mathrm{a}$ & $3.17 \mathrm{a}$ & $3.26 \mathrm{a}$ & $3.44 \mathrm{a}$ & $3.42 \mathrm{a}$ & $3.31 \mathrm{a}$ & $3.34 \mathrm{a}$ & $3.12 \mathrm{a}$ \\
\hline
\end{tabular}

Keterangan: Angka-angka yang diikuti huruf yang sama pada setiap baris berarti tidak berbeda pada uji lanjutan Jarak Berganda Duncan (DMRT) pada tingkat kepercayaan 95\% $(\dot{\alpha}=0,05)$. 
Tabel 4. Sifat fisik vulkanisat karet pada berbagai perlakuan.

\begin{tabular}{lcccccccc}
\hline \multicolumn{1}{c}{ Parameter } & \multicolumn{4}{c}{ Penyemprotan asap cair } & \multicolumn{4}{c}{ Tanpa penyemprotan } \\
\cline { 2 - 8 } & 6 hari & 8 hari & 10 hari & Kontrol & 6 hari & 8 hari & 10 hari & Kontrol \\
\hline $\begin{array}{l}\text { Kekerasan } \\
\text { (Shore A) }\end{array}$ & $38 \mathrm{a}$ & $38 \mathrm{a}$ & $38 \mathrm{a}$ & $38 \mathrm{a}$ & $36 \mathrm{a}$ & $37 \mathrm{a}$ & $37 \mathrm{a}$ & $38 \mathrm{a}$ \\
$\begin{array}{l}\text { Kuat tarik } \\
\left(\mathrm{N} / \mathrm{mm}^{2}\right)\end{array}$ & $26,3 \mathrm{a}$ & $30,3 \mathrm{a}$ & $28,0 \mathrm{a}$ & $28,8 \mathrm{a}$ & $27,8 \mathrm{a}$ & $28,9 \mathrm{a}$ & $30,6 \mathrm{a}$ & $30,2 \mathrm{a}$ \\
$\begin{array}{l}\text { Modulus 500\% } \\
\left(\mathrm{N} / \mathrm{mm}^{2}\right)\end{array}$ & $4,0 \mathrm{a}$ & $4,2 \mathrm{a}$ & $4,1 \mathrm{a}$ & $4,0 \mathrm{a}$ & $4,1 \mathrm{a}$ & $4,2 \mathrm{a}$ & $4,2 \mathrm{a}$ & $4,6 \mathrm{a}$ \\
$\begin{array}{l}\text { Perpanjangan putus } \\
(\%)\end{array}$ & $770 \mathrm{~b}$ & $810 \mathrm{a}$ & $790 \mathrm{ab}$ & $770 \mathrm{~b}$ & $810 \mathrm{a}$ & $810 \mathrm{a}$ & $820 \mathrm{a}$ & $800 \mathrm{ab}$ \\
\hline
\end{tabular}

Keterangan: Angka-angka yang diikuti huruf yang sama pada setiap baris berarti tidak berbeda pada uji lanjutan Jarak Berganda Duncan (DMRT) pada tingkat kepercayaan 95\% $(\dot{\alpha}=0,05)$

Kuat tarik dan modulus 500\% vulkanisat yang diproses dari blanket berbagai perlakuan relatif sama. Kuat tarik vulkanisat dari blanket yang disemprot asap cair berkisar antara 26,3-30,3. Sedangkan vulkanisat yang diproduksi dari blanket tanpa penyemprotan asap cair sekitar 27,8-30,2.

Perlakuan penyemprotan memberikan pengaruh yang signifikan terhadap perpanjangan putus vulkanisat yang dihasilkan. Vulkanisat yang diproduksi dari blanket dengan perlakuan penyemprotan asap cair umumnya mempunyai perpanjangan putus lebih rendah dibandingkan tanpa penyemprotan. Perpanjangan putus vulkanisat dari blanket yang disemprot asap cair sekitar $770-810 \%$. Sedangkan vulkanisat blanket tanpa penyemprotan mempunyai perpanjangan putus berkisar $800-820 \%$. Angka perpanjangan putus ini menunjukkan sifat elastisitas karet alam. Semakin tinggi nilai perpanjangan putus, maka semakin elastisitas karet alam (Basseri, 2008).

\section{KESIMPULAN}

Aplikasi penyemprotan asap cair pada blanket karet alam mampu meningkatkan mutu teknis karet alam terutama nilai Po dan PRI karet alam. Dengan penyemprotan asap cair, lama penggantungan blanket dapat dipersingkat menjadi 6-8 hari yang sebelumnya 10-12 hari. Blanket yang disemprot asap cair mempunyai waktu matang optimum sekitar 15 menit 19 detik dan waktu terjadinya pravulkanisasi sekitar 3 menit 22 detik. Nilai ini secara umum menunjukkan bahwa karakteristik vulkanisasi blanket disemprot asap cair lebih baik dibandingkan blanket tanpa penyemprotan. Faktor pengeringan, KKK, dan sifat fisik vulkanisat karet secara umum tidak dipengaruhi oleh perlakuan penyemprotan pada blanket.

Penelitian lebih lanjut dalam skala yang lebih besar diikuti dengan analisis finansial penggunaan asap cair dalam proses penggantungan (predrying) blanket karet alam perlu dilakukan.

\section{UCAPAN TERIMA KASIH}

Pada kesempatan ini penulis ingin menyampaikan ucapan terima kasih kepada Bapak Ir. H.M. Solichin, M.S. yang sudah membimbing dan memberikan saran/ masukan selama penelitian ini dilaksanakan.

\section{DAFTAR PUSTAKA}

Achmadi, S. S., Cifriadi, A., \& Hidayah, M. N. (2015). Redistilat asap cair dari cangkang kelapa sawit dan aplikasinya sebagai koagulan lateks. Jurnal Penelitian Karet, 33(2), 183-192.

Aguele, F. O., Idiaghe, J. A., \& Apugo-Nwosu, T. U. (2015). A study of quality improvement of natural rubber products by drying methods. Journal of Materials Science and Chemical Engineering, 3(11), 7-12, https://doi.org/10.4236/msce.2015.311002

ASTM (American Standard Testing and Material). (2014). ASTM D3184-11 Standard practice for rubber: Evalution of natural rubber. Pennsylvania, United States: ASTM.

Basseri, A. (2008). Pedoman praktek pengujian fisika. Bogor, Indonesia: Balai Penelitian Teknologi Karet.

BSN (Badan Standardisasi Nasional). (2000). Standar Nasional Indonesia SNI 06-1903-2000: Standar Indonesian Rubber. Jakarta, Indonesia: BSN.

Cifriadi, A. (2013). Penggunaan lindi hitam sebagai bahan pelunak dalam kompon karet alam. Jurnal 
Penelitian Karet, 31(1), 20-29.

Ditjenbun. (2015). Statistik perkebunan Indonesia 2014-2016. Jakarta, Indonesia: Kementerian Pertanian.

Ekphon, A., Ninchuewong, T., Tirawanichakul, S., \& Tirawanichakul, Y. (2013). Drying model, shrinkage and energy consumption evaluation of air dried sheet rubber drying system for small enterprise. Advanced Materials Research, 622623, 1135-1139, https://doi.org/10.4028/www. scientific.net/AMR.622-623.1135

Intapun, J., Sainte-Beuve, J., Bonfils, F., \& Vaysse, L. (2009). Characteristics of natural rubber cup coagula maturation conditions and consequences on dry rubber properties. Journal of Rubber Research, 12(4), 171-184.

Jayanthy, T., \& Sankaranarayanan, P. E. (2005). Measurement of dry rubber content in latex using microwave technique. Measurement Science Review, 5(3), 50-54.

Jovanovici, V., Budinski-simendic, J., Samarzija, S., \& Marinovic-cincovic, M. (2009). The influence of carbon black on curing kinetics and thermal aging of acriylonitrile butadiene rubber. Chemical Industry and Chemical Engineering Quarterly, 15(4), 283-289, https://doi.org/10.2298/CICEQ0904283J

Karseno, D., \& Rahayu, K. (2002). Daya hambat asap cair kayu karet terhadap bakteri pengkontaminan lateks dan ribbed smoke sheet. Agritech, 21(1), $10-15$.

Kumar, R. R., Hussain, S. N., \& Philip, J. (2007). Measurement of dry rubber content of natural rubber latex with a capacitive transducer. Journal of Rubber Research, 10(1), 17-25.

Ng, M. X., Tham, T. C., Ong, S. P., \& Law, C. L. (2015). Drying kinetics of technical specified rubber. Information Processing in Agriculture, 2(1), 64-71, https://doi.org/10.1016/j.inpa.2015.05.001

Prasertsit, K., Rattanawan, N., \& Ratanapisit, J. (2011). Effects of wood vinegars as an additive for natural rubber products. Journal of Science and Technology, 33(4), 425-430.

Prasetyowati, P., Hermanto, M., \& Farizy, S. (2014). Pembuatan asap cair dari cangkang buah karet sebagai koagulasi lateks. Jurnal Teknik Kimia, 20(4), 14-20.

Sannia, B., Ismono, R. H., \& Viantimala, V. (2013). Hubungan kualitas karet rakyat dengan tambahan pendapatan petani di desa program dan nonprogram. Jurnal Ilmu-Ilmu Agribisnis, 1(1), 36-43.

Solichin, M. (2007). Studi pengolahan sit asap (RSS) dan karet remah dengan menggunakan sinar matahari sebagai pengeringan awal dan asap cair sebagai pembeku dan pengawet (Laporan
Akhir). Balai Penelitian Sembawa, Indonesia.

Solichin, M. (2005). Optimasi produksi asap cair yang ramah lingkungan sebagai koagulan lateks, penanganan limbah bau dan cair dalam pengolahan karet remah dan sit asap (Laporan Akhir). Balai Penelitian Sembawa, Indonesia.

Solichin, M., \& Anwar, A. (2003). Pengaruh penggumpalan lateks, perendaman dan penyemprotan bokar dengan asap cair terhadap bau bokar, sifat teknis, dan sifat fisik vulkanisat. Jurnal Penelitian Karet, 21, 45-61.

Solichin, M., Pramuaji, I., \& Anwar, A. (2005). Deorub K sebagai pembeku dan pencegah timbulnya bau busuk karet. Dalam Workshop Bahan Pembeku Asap Cair yang Ramah Lingkungan. Palembang, Indonesia: Pusat Penelitian Karet.

Suparto, D., \& Santosa, A. M. (2008). Kimia dan teknologi vulkanisasi. Dalam Makalah kursus teknologi barang jadi karet. Bogor, Indonesia: Balai Penelitian Teknologi Karet - Pusat Penelitian Karet.

Supraptiningsih, S., \& Sarengat, N. (2014). Pemanfaatan limbah padat industri karet remah (crumb rubber) untuk pembuatan kompos. Majalah Kulit, Karet dan Plastik, 30(1), 35-42, https://doi.org/10.20543/mkkp.v30i1.122

Syarifa, L. F., Agustina, D. S., \& Nancy, C. (2013). Evaluasi pengolahan dan mutu bahan olah karet rakyat (bokar) di tingkat petani karet di Sumatera Selatan. Jurnal Penelitian Karet, 31(2), 139148 , https://doi.org/10.22302/jpk.v31i2.141

Tedjaputra, N., Solichin, M., \& Anwar, A. (2007). Penggunaan asap cair Deorub dalam pengolahan RSS. Jurnal Penelitian Karet, 25(1), 83-94.

Tham, T. C., Hii, C. L., Ong, S. P., Chin, N. L., Abdullah, L. C., \& Law, C. L. (2014). Technical review on crumb rubber drying process and the potential of advanced drying technique. Agriculture and Agricultural Science Procedia, 2, 26-32, https://doi.org/10.1016/j.aaspro.2014.11.005

Vachlepi, A., \& Solichin, M. (2008). Aplikasi formula asap cair (Deorub K) sebagai penggumpal lateks. Jurnal Penelitian Karet, 27(2), 80-87.

Wiyanto, W., \& Kusnadi, N. (2013). Faktor-faktor yang mempengaruhi kualitas perkebunan rakyat (kasus perkebunan rakyat di Kecamatan Tulang Bawang Tengah, Kabupaten Tulang Bawang Lampung). Jurnal Agribisnis Indonesia, 1(1), 39-58.

Zhong, J. P., Li, C., Kong, L., \& She, X. D. (2009). Study on the properties of natural rubber during maturation. Journal of Polymer Materials, 26(3), 351-360. 
